\title{
Agoraphobia without a History of Panic Disorder
}

National Cancer Institute

\section{Source}

National Cancer Institute. Agoraphobia without a History of Panic Disorder. NCI

Thesaurus. Code C34363.

An anxiety disorder characterized by agoraphobia in the absence of a history of panic attacks; the individual fears incapacitation or humiliation in open, public places or situations due to panic-like symptoms rather than a full-blown panic attack. 